Jurnal Pena Sains Vol. 8, No. 1, April, 2021

p-ISSN: 2407-2311

e-ISSN: 2527-7634

\title{
THE EFFECT OF ADVERSITY QUOTIENT AND ATTITUDES OF STUDENTS ON THE STUDENT'S PHYSICAL LEARNING ACHIEVEMENTS
}

\author{
Nor Hanifah ${ }^{1}$, Abdul Salam ${ }^{2}$, Dewi Dewantara ${ }^{3}$ \\ ${ }^{1,2,3}$ Program Studi Pendidikan Fisika, Fakultas Keguruan dan Ilmu Pendidikan, Universitas Lambung Mangkurat \\ dewantara_pfis@ulm.ac.id
}

DOI: $10.21107 / j p s . v 8 i 1.9221$

\begin{abstract}
This ex post facto study aimed to reveal the influence of adversity quotient and attitudes students on physics learning achievement. The population of this study was all of twelvh graders of Public Senior High School (SMAN) 10 Banjarmasin City. The sample was determined by simple random sampling. The instruments used were questionnaires. The research data were analyzed by using SPSS statistical data processing program. The results showed that adversity quotient and attitudes students were in the very high and positive category, and than had a significant effect on physics learning achievement of Public Senior High School (SMAN) 10 Banjarmasin City.
\end{abstract}

Keywords: adversity quotient, attitudes students toward physics, and physics learning achievement

\footnotetext{
${ }^{3}$ Corresponding Author
} 


\section{Introduction}

Science and technology play an important role and can influence developments in all fields, even science and technology can develop better human resources. The way that can be taken for human resource development is through education. Education is a conscious effort or regular activity and planning with the intention of changing or developing desired behavior. Only with quality education can we build an edge in the face of increasingly global competition.

In formal education, learning shows a change, which is positive in nature so that at the final stage new skills, experiences, skills and knowledge will be acquired. The results of the Third Mathematics Science Study (TIMSS) survey which includes performance, expectation, and perspective on both math-science for high school students, Indonesia is in the bottom 6 of 38 countries. Research findings from the Program for International Student Assessment (PISA) show that in reading, math, and science literacy, students aged 15 years in Indonesia are very low. These findings show, in reading literacy, $69 \%$ of Indonesian students are at the proficiency level 1 and below 1 . Therefore, from an early age we must improve the quality of human resources and create a good moral and quality young generation. To make quality education can be determined by the quality of processing and management, with the assumption that in order to improve the quality of education, the teaching and learning process must be addressed properly.

In improving the quality of education, one of which is influenced by the quality teaching and learning process so that it will produce quality students as well. To realize a comfortable and conducive teaching and learning process for students, educators must be able to actualize all available learning resources. So it can be said that the success or failure of the teaching and learning process depends on the learning process experienced by students themselves both at school and in the family environment. Djamarah and Zain (2010) state that learning is a process of changing behavior thanks to experience and training. Creating comfortable conditions will make it easier for students to achieve learning goals. Teachers as educators are required to be able to be professional in carrying out their duties. Along with the development of the era, an educator must also be able to adapt to the existing educational environment. Especially this concerns the basic abilities that must be possessed by an educator, so that the goals of education can be achieved. Anwar
(2018: 23) says, professionalism is a term that refers to a mental attitude in the form of commitment from members of a profession to always create and improve their professional quality. A teacher who has high professionalism will be reflected in his mental attitude and commitment to the realization and improvement of professional quality through various means and strategies.

If an educator is able to act professionally, it is expected that students can participate in teaching and learning activities well. Teaching and learning activities given to students emphasize the mastery of knowledge, skills, and the process of changing attitudes towards a better direction. Each individual educator must be able to accustom students to be consistent in learning and doing assignments given on time so that it will improve student achievement, especially in the field of physics.

To improve students' physics learning achievement, several factors influence it, including internal factors and external factors from students. Syah (2010) said that physics learning achievement is influenced by some factors, namely: internal, external factors and learning approaches. If the use of these factors is maximized, it will greatly assist students in improving learning achievement. In this case, one part of the internal factor is the Adversity quotient. Internal factors are a strong desire or motivation from within students. The enthusiasmthat arises from within a person is expected to be more supportive of enthusiasm, because in essence the best desire is that which comes out of a person himself. The success of students in the teaching and learning process depends on how these students are able to be consistent. Students who haveconsistent will be able to align their attitudes and behaviors to the expected goals.

Based on the experience and information obtained at school, there are still students who always feel afraid and tense when taking physics lessons, there are also students who feel that they don't have any advantages in physics lessons, there are also those who always feel anxious about facing exams, and there are also those who worry if they get a turn to come forward, afraid to ask questions. According to Supardi (2015), in facing difficulties, it is necessary to have endurance fighting power so as to be able to make difficulties as challenges and opportunities, this is what Stoltz conceptualized as an adversity quotient. This Adversity Quotient (AQ) can turn barriers into opportunities because this intelligence determines how far individuals are able to survive and 
overcome difficulties. Self-consistency in continuing to excel also decreases in line with the students' low ability to overcome difficulties they face. In the learning process, individuals who have a good adversity quotient level will tend to be able to overcome the difficulties they face, after the difficulties facing them are resolved, students must be able to be consistent, have a firm stance, and focus on doing the main task as students, namely learning.

In addition to the adversity quotient, their attitude towards physics can also affect learning achievement. Students' attitudes towards physics are intended to be affective reactions in students as a tendency to avoid or approach physics, and are colored with elements of pleasure or displeasure with physics lessons. Based on research by Nurjannah (2018) students of Makassar State University, attitudes towards subjects partially have a significant effect on learning outcomes and motivation. From the description of the problem above, the researcher is interested in examining the effect of the adversity quotient and students' attitudes on physics learning achievement.

This study aims to describe the effect of adversity quotient, student attitudes, and student achievement in class XII SMAN 10 Banjarmasin. The specific objectives of this study are as follows: 1) To describe the level of adversity quotient, student attitudes, and student achievement in physics class XII-MIA SMAN 10 Banjarmasin. 2) Describe the joint effect of adversity quotient and student attitudes on student learning achievement in physics class XII-MIA SMAN 10 Banjarmasin. 3) Describe the effect partially between the adversity quotient on the physics learning achievement of students in class XII-MIA SMAN 10 Banjarmasin. 4) Describe the effect partially between student attitudes on student learning achievement in physics class XII-MIA SMAN 10 Banjarmasin.

\section{Research Methods}

This research is a quantitative paradigm with ex-post facto research. This study will reveal the effect of adversity quotient and student attitudes on student achievement in physics class XII SMAN 10 Banjarmasin. When this research was conducted in the even semester of 2019/2020. The population of this study were students of class XII of the MIA Department of SMAN 10 Banjarmasin in the 2019/2020 school year which consisted of 3 class XII majoring in MIA with a total of 101 students. With the simple random sampling technique, 45 samples were selected.
Collecting research data using a questionnaire/questionnaire derived from the adversity quotient instrument and student attitudes that have been standardized. Furthermore, the search for the value of the Daily Examination in physics subjects to measure student achievement. Each questionnaire is arranged based on the indicators described in Table 1 and Table 2.

Table 1. Indicators of Adversity Quotient

\begin{tabular}{ll}
\hline No & Indicator \\
\hline 1 & Control \\
2 & Originality and Ownership \\
4 & Reach \\
5 & Endurance \\
\hline
\end{tabular}

Table 2. Indicators of Student Attitudes

\begin{tabular}{ll} 
No & Indicator \\
\hline 1 & The nature of reasoning in physics \\
2 & The development and benefits of physics \\
3 & $\begin{array}{l}\text { Physics-related literature (physics books) } \\
4\end{array}$ \\
People in direct contact with physics (physics \\
teacher)
\end{tabular}

The data analysis technique used is statistical analysis which includes descriptive analysis and inferential analysis. This descriptive analysis is used to determine the state of the data based on each research variable using the mean, median, mode, variance, standard deviation, minimum value, maximum value, frequency distribution table, and percentage. As part of the descriptive analysis, the scores of each research variable were also categorized based on the appropriate criteria in Table 3 to Table 5. Data calculations and analysis were carried out with the help of the Statistical Product and Service Solutions (SPSS) program.

Table 3. Interpretation of Learning Achievement Categories

\begin{tabular}{c|c}
\hline Learning Achievement & Category \\
\hline $90-100$ & Very High \\
$80-89$ & High \\
$65-79$ & Quiet \\
$55-64$ & Poor \\
$0-54$ & Bad \\
\hline
\end{tabular}


Table 4. Interpretation of Adversity Quotient Categories

\begin{tabular}{cc} 
Interval of Score & Category \\
\hline $0.00-14.17$ & Bad \\
$14.18-39.21$ & Quiet \\
$39.22-61.23$ & High \\
$61.24-72.37$ & Very High \\
\hline
\end{tabular}

Table 5. Categories of Student Attitudes

\begin{tabular}{ll} 
Interval of Score & Category \\
\hline $64-105$ & Positive \\
\hline $21-63$ & Negative \\
\hline
\end{tabular}

Inferential analysis is used to test the proposed research hypothesis. Before testing the hypothesis, first the normality test, multicollinearity test, homogeneity test and autocorrelation test are held. Furthermore, hypothesis testing consists of partial test, simultaneous test, determination coefficient and correlation coefficient.

\section{Result and Discussion}

Descriptively, the data presented from the analysis showed that in general students had learning achievement in the very high category. Adversity quotient of attitude towards physics has a positive effect on learning achievement in physics. Adversity quotient for XII grade students of SMAN 10 Banjarmasin, from the results of data analysis in table 9, it is known that class XII students of SMAN 10 Banjarmasin have adversity quotient at a very high level of 69.11.

The attitudes of students in class XII of SMAN 10 Banjarmasin, from the results of data analysis, it is known that positive student attitudes towards school learning are based on table 11. In general, students' attitudes towards physics are in the positive category, namely the average score of the student attitude questionnaire between 64 and 105 totaling 40 people students with a percentage of $88.9 \%$.

Student achievement in class XII SMAN 10 Banjarmasin, from the results of the data analysis in table 13, it is known that the learning achievement of students in class XII-MIA SMAN 10 Banjarmasin is in the very high category with a percentage of $100 \%$. This is confirmed by the Physics subject teacher who is at SMAN 10 Banjarmasin, according to Mrs. Eliana, the students of class XII MIA at SMAN 10
Banajrmasin have high desire and curiosity so that they are enthusiastic in learning physics.

\section{Inferential Analysis}

The normality test is used to determine whether the sample data in the study used comes from a normally distributed population or not. Based on Table 6 the results of normality testing, the normality test for the residual error of the data regression model for the independent variables (adversity quotient and student attitudes towards physics) and the dependent variable (physics learning achievement) was obtained using the Kolmogorof-Smirnov test showing a significance value of 0.825 which is also greater than the alpha value is 0.05 so it can be said that the research sample data comes from a normally distributed population.

Table 6. Normality Test Results

\begin{tabular}{ccc}
\hline Sig. Value & Alpha & \\
\hline 0,825 & 0,05 & Berdistribusi Normal \\
\hline
\end{tabular}

Linearity test aims to determine whether the independent variables and variables have a linear or not significant relationship. Based on table 7 , the test results obtained the value of deviation from Linearity sig. the two independent variables, namely adversity quotient and student attitudes are 0.853 and 0.342 where both results are greater than the alpha value of 0.05 , so it can be said that there is a linear relationship between the independent variables (adversity quotient and student attitudes towards physics) and the dependent variable (achievement). learn physics).

Table 7. Adversity Quotient Linearity Test Results

\begin{tabular}{cccc}
\hline Variable & $\begin{array}{c}\text { Sig. } \\
\text { Value }\end{array}$ & Alpha & \\
\hline $\begin{array}{c}\text { Adversity } \\
\text { Quotient }\end{array}$ & 0,853 & 0,05 & $\begin{array}{c}\text { There is a } \\
\text { Relationship }\end{array}$ \\
\hline attitudes & 0,342 & 0,05 & $\begin{array}{c}\text { There is a } \\
\text { Relationship }\end{array}$ \\
\hline
\end{tabular}

The multicollinearity test is used to determine whether or not a linear relationship exists between the independent variables or the independent variables in the regression model. Based on table 8 , the test results obtained the value of the variance inflation factor (VIF) of the two independent variables, namely adversity quotient and student attitudes are the same, namely 1.057, meaning that both are smaller than the value of 10 , so it can be said that there is no multicollinearity between the independent variables in the regression model. 
Table 8 Multicollinearity Test Results

\begin{tabular}{cccc}
\hline Variable & $\begin{array}{c}\text { VIF } \\
\text { Value }\end{array}$ & $\begin{array}{c}\text { Compariso } \\
\text { n }\end{array}$ & \\
\hline $\begin{array}{c}\text { Adversity } \\
\text { Quotient }\end{array}$ & 0.057 & 10 & No \\
\hline Attitudes & 0.057 & 10 & Multicolineolinearity \\
\hline
\end{tabular}

The homogeneity test is used to determine whether the variance of the data is homogeneous or not. Based on Table 9, the results of the analysis show that the opportunity value is 0.268 which is greater than the $\alpha$ value of 0.05 , so it can be concluded that the variance of the data is homogeneous.

Table 9 Homogeneity Test Results

\begin{tabular}{ccc}
\hline Nilai Sig. & Alpha & Keterangan \\
\hline 0.268 & 0.05 & Homogenitas \\
\hline
\end{tabular}

The autocorrelation test is used to determine whether or not there is a deviation from the classic autocorrelation assumption, namely the correlation between the residuals in one observation and other observations in the regression model. Based on table 10, the results of the autocorrelation test data analysis obtained the Durbin-Watson (DW) value of 1.804 which is located between $\mathrm{dU}$ and 4-dU, so it can be concluded that there is no autocorrelation.

Table 10. Autocorrelation Test Results

\begin{tabular}{cccc}
\hline d & dU & 4-dU & Keterangan \\
\hline 1.804 & 1.614 & 2.386 & No Autocorrelation \\
\hline
\end{tabular}

The effect of adversity quotient, student attitudes towards learning achievement of physics class XII students of SMAN 10 Banjarmasin simultaneously

Hypothesis test:

There is an effect of adversity quotient, student attitudes towards learning achievement of physics class XII students of SMAN 10 Banjarmasin simultaneously.

Based on Table 11, the $\mathrm{F}$ test or what is known as the ANOVA (Analysis of variance) test, obtained the calculated $\mathrm{F}$ value of 37.004 with an opportunity value (sig.) Of 0.000 which is smaller than $\alpha 0.05$, thus the hypothesis is accepted which states that adversity quotient and attitude students simultaneously affect the physics learning achievement in class XII students of SMAN 10 Banjarmasin.
Table 11. F Test Results

\begin{tabular}{cccc}
\hline F & Sig. Value & Alpha & \\
\hline 37.004 & 0.000 & 0.05 & $\mathrm{H}_{0}$ rejected \\
\hline
\end{tabular}

The multiple regression equation data variable adversity quotient $\left(\mathrm{X}_{1}\right)$ and student attitudes $\left(\mathrm{X}_{2}\right)$ with learning achievement of physics $(\mathrm{Y})$ together is $\mathrm{Y}=93.457+0.12 \mathrm{X}_{1}+0.022 \mathrm{X}_{2}$. The amount of the coefficient of determination $\left(\mathrm{R}^{2}\right)$ is 0.638 , this means that the influence or contribution together of the independent variable adversity quotient and attitudes towards physics on student achievement is $63.8 \%$.

The effect of adversity quotient on the physics learning achievement of class XII students of SMAN 10 Banjarmasin

Hypothesis test:

Adversity quotient has a positive effect on physics learning achievement in class XII students of SMAN 10 Banjarmasin.

Based on Table 12, the results of t-test calculations for the adversity quotient variable, obtained a t-value of 2.587 with an opportunity value (sig.) Of 0.013 which is smaller than 0.05 , thus the adversity quotient has a positive effect on physics learning achievement in class XII SMAN 10 Banjarmasin is acceptable.

Table 12. t-test results from the Adversity Quotient

\begin{tabular}{ccccc}
\hline Variable & T & Sig. Value & Alpha & \\
\hline $\begin{array}{r}\text { Adversity } \\
\text { Quotient }\end{array}$ & 2.587 & 0.013 & 0.05 & $\mathrm{H}_{0}$ rejected \\
\hline
\end{tabular}

The effect of student attitudes on student achievement in physics learning class XII SMAN 10 Banjarmasin

Hypothesis test:

Student attitudes have a positive effect on physics learning achievement in class XII students of SMAN 10 Banjarmasin.

Based on table 13, the results of the t-test calculation for the student's attitude variable, it was obtained the $t$ value of 7.380 with an opportunity value (sig.) Of 0.000 which was smaller than 0.05 , thus the student's attitude had a positive effect on physics learning achievement in class XII SMAN students. 10 Banjarmasin is acceptable. 
Table 13. The results of the t test for students' attitudes

\begin{tabular}{ccrcc}
\hline Variable & t & Sig. Value & Alpha & \\
\hline $\begin{array}{c}\text { Attitude of } \\
\text { Students }\end{array}$ & 7.380 & 0.000 & 0.05 & $\mathrm{H}_{0}$ rejected \\
\hline
\end{tabular}

Based on the descriptions that have been stated, it is clear that the adversity quotient has implications for improving student learning achievement. Students' learning achievement mostly depends on adversity quotient as their intelligence/ability to fight in facing difficulties or problems.

\section{Conclusion}

The results of descriptive statistical analysis showed that the students of class XII SMAN 10 Banjarmasin were in the very high category with a mean score of 69.11; student attitudes towards physics are in the positive category with a mean score of 77.17; and physics learning achievement is in the very high category with an average score of 95.98. Furthermore, the results of inferential analysis show that the adversity quotient and students' attitudes have a significant effect on the physics learning achievement of class XII students of SMAN 10 Banjarmasin.

\section{References}

Abbas, S. (2010). Peningkatan prestasi belajar sains dengan menggunakan pendekatan kontekstual. Tesis. Program Pascasarjana Universitas Negeri Yogyakarta. Tidak dipublikasikan.

Abdullah. (2010). Pengaruh pembelajaran matematika berbantuan komputer terhadap prestasi belajar matematika. Tesis. Program Pasca Sarjana Universitas Negeri Yogyakarta. Tidak dipublikasikan.

Achdiyat, M. (2018). Sikap Cara Belajar dan Prestasi Belajar. Jurnal Ilmiah. 5(1), 4958.

Azwar, S. (2012). Reliabilitas dan Validitas. Yogyakarta: Pustaka Pelajar.

Bintari, P. W. N. (2011). Adversity quotient dengan prestasi akademik pada anggota peleton inti siswa SMA. Skripsi. Jakarta:Universitas Islam Indonesia.
Dharma Kesuma dkk. (2012). Pendidikan Karakter Kajian Teori dan Praktik di Sekolah. Bandung: PT Remaja Rosdakarya.

Djamarah. (2012). Psikologi Belajar. Jakarta: PT Rineka Cipta.

Fitriani, Mela Dara. (2019). Penerapan Model Pembelajaran Inkuiri dalam Meningkatkan Prestasi Belajar Siswa Kelas V Subtema Manusia dan Lingkungan. Skripsi. Bandung: Universitas Pasundan.

Hamdani. (2011). Strategi Belajar Mengajar. Bandung: Pustaka Setia.

Herbiadi, A. (2015). Hubungan antara sikap dengan hasil belajar siswa dalam mata pelajaran Fisika di SMA. Jurnal Pendidikan, 2(1), 48-56.

Leonard \& Amanah, N. (2014). Pengaruh Adversity Quotient (AQ) dan Kemampuan Berpikir Kritis terhadap Prestasi Belajar Matematika. Perspektif Ilmu Pendidikan, 28(1), 55-64.

Mustaqim, A. F. (2019). True of Myself. Jakarta: Fariz AM Group.

Nas, S. (2017). Pengaruh Adversity Quotient, Motivasi Belajar, dan Persepsi Siswa tentang Cara Mengajar Guru terhadap Hasil Belajar Matematika Siswa Kelas IX SMPN Se-Kecamatan Wara Utara Kota Palopo. Jurnal Pendidikan. 3(2), 124-150.

Noor, J. (2012). Metodologi Penelitian: Skripsi, Tesis, Disertasi \& Karya Ilmiah. Jakarta: Kencana.

Nurfiana, A. (2012). Hubungan Adversity Quotient dengan Prestasi Belajar Matematika pada Siswa Kelas Ix A SMP Negeri 1 Tempel. Tesis. Yogyakarta: Universitas Negeri Yogyakarta.

Nurjannah. (2018). Kemampuan berpikir divergen, adversity quotient, sikap terhadap matematika, persepsi tentang cara mengajar guru, motivasi dan hasil belajar matematika. Jurnal Vidya Karya, 33(2), 168-180.

Pratama, D. S. (2017). Hubungan antara adversity quotient dan self efficacy dengan menggunakan model pbl terhadap hasil 
Hanifah, Salam, \& Dewantara

belajar fisika siswa SMA. Jurnal Inovasi Pendidikan, 1(2), 88-93.

Siregar \& Harahap. (2019). Strategi dan Teknik Penulisan Karya Tulis Ilmiah dan Publikasi. Yogyakarta: CV Budi Utama.

Slameto. (2012). Belajar dan Faktor-faktor yang Mempengaruhinya. Jakarta: PT Rineka Cipta.

Soebardhy \& Sumani. (2020). Kapita Selekta Metedologi Penelitian. Surabaya: CV Qiara Media.

Sudjana, N. (2010). Cara Belajar Siswa Aktif dalam Proses Belajar Mengajar. Bandung: Sinar Baru Algensindo.

Supardi. (2015). Pengaruh adversity quotient terhadap prestasi belajar matematika. Jurnal Formatif, 3(1), 61-71.

Syah, M. (2010). Psikologi Belajar. Jakarta: Rajagrafindo Persada.

Syaiful Bahri Djamarah. (2012). Prestasi Belajar Dan Kompetensi Guru. Surabaya: Usaha Nasional.

Tafsir, A. (2008). Ilmu Pendidikan dalam Perspektif Islam. Bandung: PT Remaja Rosdakarya.

Usman, H. \& Akbar, P.S. (2012). Pengantar Statistika. Jakarta: PT Bumi Aksar. 